\title{
The Rio Grande Rise is a Large Igneous Province, not a detached microcontinent.
}

\author{
PATRICK A. HOYER ${ }^{1}$, KARSTEN M. HAASE ${ }^{1}$, MARCEL \\ REGELOUS $^{1}$, JOHN M. O'CONNOR ${ }^{1,2}$, STEPHAN \\ HOMRIGHAUSEN $^{3}$ AND WOLFRAM H. GEISSLER ${ }^{4}$ \\ ${ }^{1}$ GeoZentrum Nordbayern, Friedrich-Alexander-Universität \\ (FAU) Erlangen-Nürnberg \\ ${ }^{2}$ Vrije Universiteit Amsterdam \\ ${ }^{3}$ Geomar - Helmholtz-Zentrum für Ozeanforschung Kiel \\ ${ }^{4}$ Alfred-Wegener-Institut Helmholtz-Zentrum für Polar- und \\ Meeresforschung Bremerhaven \\ Presenting Author: patrick.hoyer@fau.de
}

The Rio Grande Rise (RGR) is one of the most prominent bathymetric features in the South Atlantic Ocean. It has long been assumed that this massive oceanic plateau is a Late Cretaceous Large Igneous Province related to the Tristan-Gough mantle plume. However, recent geophysical and petrological studies suggest that it might be a fragment of a detached continental margin that has been preserved as a 'microcontinent' embedded in plume-influenced oceanic crust $[1,2]$.

Here we present new geochemical results from cruise MSM82 in spring 2019, that carried out geophysical measurements and petrological sampling. We measured major and trace element concentrations of 47 whole rock samples dredged along the flanks of the rift valley cutting through the eastern (E) and western (W) parts of the RGR. Further, we provide new geochemical data from DSDP Site 516 (at the WRGR) and the Jean Charcot Seamount Chain (JCSC), which extends from the WRGR $\sim 500 \mathrm{~km}$ to the NW close to the Brazilian coast. Based on trace element modelling, we show that the WRGR was formed by at least two magmatic stages changing from high degrees of shallow mantle melting to deeper melting of a more enriched source. We suggest that the first magmatic stage was associated with melting at a plume-influenced spreading centre, while the second magmatic stage reflect intraplate volcanism possibly related to the JCSC. In contrast, the lavas from the ERGR show high degrees of shallow mantle melting but exhibit an alkaline character and higher ratios of $\mathrm{Nb} / \mathrm{Zr}, \mathrm{Nb} / \mathrm{Yb}$ and $\mathrm{Th} / \mathrm{Yb}$ than depleted MORB. Thus, we suggest that the ERGR lavas were formed at or close to a plume-influenced spreading centre similar to the first magmatic stage of the WRGR. All samples from the RGR have high $\mathrm{Nb} / \mathrm{Th}, \mathrm{Ce} / \mathrm{Pb}$ and $\mathrm{Nb} / \mathrm{La}$ similar to oceanic basalts and do not vary with $\mathrm{MgO}$, indicating that they have not undergone significant contamination by a continental component. Therefore, we find no geochemical evidence for continental crust below the RGR and suggest it formed by magmatic processes.

[1] Mohriak et al. (2010), Petro. Geos. 16 (3), 231-245

[2] Santos et al. (2019) Terra Nova 31, 424-429 